\title{
A ESPIONAGEM DOS ESTADOS UNIDOS DA AMÉRICA E A VIOLAÇÃO DA PRIVACIDADE DE DADOS PESSOAIS DOS BRASILEIROS NA INTERNET
}

\section{THE ESPIONAGE OF THE UNITED STATES OF AMERICA AND THE VIOLATION OF PRIVACY OF PERSONAL DATA OF BRAZILIANS ON THE INTERNET}

\begin{abstract}
Márcio de Souza Bernardes
Doutorando em Direito pela Universidade Federal de Santa Catarina, Mestrado em Direito pela Universidade de Santa Cruz do Sul, Especialista em Direito Processual Civil pela Universidade Luterana do Brasil - ULBRA, Graduação em Direito pela Universidade Federal de Santa Maria. Advogado, atualmente é membro do conselho de subseção - Ordem dos Advogados do Brasil - Subseção de Santa Maria - RS. Professor do Centro Universitário Franciscano e em cursos de pós-graduação lato senso junto à FADISMA, IMED, UCS, UNIVALI. E-mail: msbernardes@hotmail.com
\end{abstract}

Rodrigo Aguiar da Silva

Graduando do Curso de Direito do Centro Universitário Franciscano. Estagiário do Ministério Público do Trabalho. E-mail: rodrigoaguiar_silva@hotmail.com

\begin{abstract}
RESUMO
0 presente artigo versa sobre as consequências políticas e jurídicas da espionagem dos Estados Unidos da América, especialmente no que tange à violação da privacidade de dados pessoais dos brasileiros na Internet. Diante disso, surge o seguinte problema a ser resolvido: o controle estatal dos Estados Unidos da América é justificável mesmo infringindo o direito fundamental da privacidade do sigilo de dados pessoais dos brasileiros na Internet, com fundamento na proteção da segurança pública estadunidense? Para tanto, utilizou-se o método dialético de abordagem, bem como os métodos de procedimento histórico, bibliográfico e comparativo, analisando-se a importância de proteção da privacidade no âmbito virtual, além de ser ponderado se houve violação à soberania brasileira no contexto atual da globalização. Por fim, examina-se a justificativa dada pelos Estados Unidos da América, fazendo-se um contraponto com a violação da privacidade de dados pessoais dos brasileiros na Internet, concluindo-se que a defesa de um único Estado não o autoriza a prejudicar todos os demais com uma espionagem virtual, diante da essencialidade da privacidade de cada indivíduo como direito humano fundamental, além de atentar contra a soberania e a democracia em âmbito internacional.
\end{abstract}

Palavras-chave: Espionagem; Privacidade; Internet; Sociedade da Informação; Globalização.

\begin{abstract}
This article discusses the political and legal consequences of espionage of the United States of America, especially in regard to the violation of privacy of personal data of Brazilians on the Internet. Thus arises the following problem to be solved: state control of the United States of America is justifiable even infringing the fundamental right of privacy of confidentiality of personal data of Brazilians on the Internet, based on the protection of the American public safety? For this, we used the dialectical method of approach and methods of history, literature and comparative procedure, analyzing the importance of privacy protection in the virtual context, besides being considered whether there was violation of Brazilian sovereignty in the face of current globalization.. Finally, it examines the justification given by the United States, making it a counterpoint to the violation of privacy of personal data in the Brazilian Internet, concluding that the defense of a State does not authorize the harm all too much like a virtual espionage, on the essentiality of the privacy of every individual as a fundamental human right, besides prejudice the sovereignty and democracy internationally.
\end{abstract}

Keywords: Espionage; Privacy; Internet; Information Society; Globalization. 


\section{SUMÁRIO}

INTRODUÇAO; 10 DIREITO FUNDAMENTAL À PRIVACIDADE DOS DADOS PESSOAIS NA INTERNET; 2 A ESPIONAGEM CIBERNÉTICA ESTADUNIDENSE NO ÂMBITO BRASILEIRO; 30 CONFLITO ENTRE A DEFESA DA SEGURANÇA PÚBLICA NORTE-AMERICANA E A PRIVACIDADE DOS BRASILEIROS NA INTERNET; CONCLUSÃO; REFERÊNCIAS.

\section{INTRODUÇÃO}

Em junho de 2013, Edward Joseph Snowden revelou a espionagem virtual por órgãos de inteligência dos Estados Unidos da América, tornando o fato mundialmente conhecido. As informações levadas a público pelo ex-técnico da CIA (Central Intelligence Agency), que teve acesso a estas quando prestava serviço terceirizado como analista de sistemas para a NSA (National Security Agency), causaram um enorme impacto no âmbito internacional, uma vez que, além do Brasil, outros países da América Latina e também da Europa haviam sido alvos da espionagem.

Conforme o delator, as comunicações de cidadãos de diversos países eram levantadas pela NSA sem qualquer tipo de consentimento ou autorização, mediante a utilização secreta de interceptadores de dados aos cabos submarinos de fibra ótica que circundam o globo, além de convencerem grandes empresas de telecomunicações a entregarem seus dados, permitindo assim uma narrativa eletrônica completa da vida dos indivíduos ao governo estadunidense ${ }^{1}$.

Entre os documentos publicados por intermédio de Snowden está o monitoramento de milhões de e-mails e ligações de brasileiros e estrangeiros em trânsito no Brasil, além da informação de que uma estação de espionagem da NSA funcionou em Brasília pelo menos até $2002^{2}$. A repercussão pública e jurídica do caso chegou ao seu ápice até então diante de novas denúncias de espionagem em setembro de 2013, quando foi noticiado que o governo brasileiro também foi objeto de vigilância norte-americana, tendo como principais alvos a Presidente da

\footnotetext{
${ }^{1}$ HARDING, Luke. Os arquivos Snowden: a história secreta do homem mais procurado do mundo. Rio de Janeiro: LeYa, 2014, p. 14.

${ }^{2}$ G1. Entenda o caso de Edward Snowden que revelou espionagem dos EUA. Disponível em: <http://g1.globo.com/mundo/noticia/2013/07/entenda-o-caso-de-edward-snowden-que-revelouespionagem-dos-eua.html>. Acesso em: 10 set. 2013.

REDESG / Revista Direitos Emergentes na Sociedade Global - www.ufsm.br/redesg v. 3, n. 1, jan-jun/2014
} 
A ESPIONAGEM DOS ESTADOS UNIDOS DA AMÉRICA E A VIOLAÇÃO DA PRIVACIDADE DE DADOS PESSOAIS DOS BRASILEIROS NA INTERNET

República e seus assessores ${ }^{3}$, além da Petrobras $^{4}$ e do Ministério de Minas e Energia ${ }^{5}$, o que revelou um desígnio político-econômico por trás da justificativa de combate ao terrorismo. Em resposta, a Presidente do Brasil, Dilma Rousseff, reagiu energicamente às denúncias em seu discurso na abertura da $68^{\mathrm{a}}$ Assembleia-Geral das Nações Unidas, onde defendeu a soberania de seu país e afirmou que a espionagem norte-americana é um caso de grave violação dos direitos humanos e das liberdades civis 6 .

Ademais, a proteção dos direitos fundamentais sempre foi de grande relevância no direito brasileiro, sobretudo após o advento da Constituição Federal de 1988, onde estes foram positivados como garantias fundamentais a todos. Entre os direitos fundamentais do ser humano elencados no artigo $5^{\circ}$ da Carta Magna está a inviolabilidade da intimidade e da vida privada, bem como dos dados pessoais sigilosos. Posto isso, verifica-se que, com a utilização cada vez mais frequente das novas tecnologias em uma sociedade informatizada, a privacidade muitas vezes é cerceada em face do uso indevido dos meios de comunicação, principalmente com o advento da Internet.

Desse modo, é preciso que o Direito acompanhe os avanços da sociedade, renovando-se a cada dia para que não fique ultrapassado, principalmente no que tange aos direitos humanos fundamentais e em relação às novas tecnologias que se modificam e evoluem com grande frequência. Com a revelação da espionagem de dados pessoais de brasileiros na Internet, é de suma importância que se analise os efeitos da espionagem norte-americana não só no direito brasileiro como também no âmbito internacional, em virtude da gravidade da violação de direitos humanos fundamentais que devem ser protegidos por todos os países, harmonicamente, em prol de um bem comum. Nesse contexto, é importante analisar se houve afronta à soberania estatal brasileira, verificando-se o novo conceito de soberania em face da globalização.

\footnotetext{
${ }^{3} \mathrm{G} 1$. Veja os documentos ultrassecretos que comprovam espionagem a Dilma. Disponível em: <http://g1.globo.com/fantastico/noticia/2013/09/veja-os-documentos-ultrassecretos-que-comprovamespionagem-dilma.html>. Acesso em: 03 set. 2013.

${ }^{4}$ G1. Petrobras foi alvo de espionagem de agência dos EUA, aponta documento. Disponível em: <http://g1.globo.com/politica/noticia/2013/09/petrobras-foi-alvo-de-espionagem-de-agencia-dos-euaaponta-documento.html>. Acesso em: 09 set. 2013.

${ }^{5} \mathrm{G} 1$. Ministério das Minas e Energia está na mira dos espiões americanos e canadenses. Disponível em: <http://g1.globo.com/fantastico/noticia/2013/10/ministerio-das-minas-e-energia-esta-na-mira-deespioes-americanos-e-canadenses.html>. Acesso em: 07 out. 2013.

${ }^{6} \mathrm{BBC}$ BRASIL. Dilma diz em Assembleia da ONU que espionagem é grave violação dos direitos humanos. Disponível em: <http://www.bbc.co.uk/portuguese/noticias/2013/09/130924_dilma_assembleia_onu_lgb.sht'ml>. Acesso em: 24 out. 2013.
}

REDESG / Revista Direitos Emergentes na Sociedade Global - www.ufsm.br/redesg v. 3, n. 1, jan-jun/2014 
A ESPIONAGEM DOS ESTADOS UNIDOS DA AMÉRICA E A VIOLAÇÃO DA PRIVACIDADE DE DADOS PESSOAIS DOS BRASILEIROS NA INTERNET

MÁRCIO DE SOUZA BERNARDES E RODRIGO AGUIAR DA SILVA

É necessário, ainda, averiguar os motivos que levaram o governo norte-americano a realizar a espionagem virtual, desde a justificativa do combate ao terrorismo em prol da segurança pública de seus cidadãos até possíveis interesses econômicos que beneficiariam o país nas relações internacionais. Diante do questionamento se este argumento seria suficiente para legitimar a interferência na vida privada dos habitantes de outros países, surgiu o problema de pesquisa do presente artigo: o controle estatal dos Estados Unidos da América é justificável a partir do momento que infringe o direito fundamental da privacidade do sigilo de dados pessoais dos brasileiros na Internet, com fundamento na proteção da segurança pública estadunidense?

Desse modo, diante de toda essa tensão diplomática decorrente da violação de um direito humano fundamental, verifica-se a importância deste artigo para discutir a relevância jurídica do caso em tela e analisar as consequências da observação eletrônica em massa pelos Estados Unidos da América. Para tanto, utilizar-se-á o método dialético de abordagem, com embasamento jurídico e doutrinário de diversos autores, visto que o objeto da pesquisa será abordado a partir de suas contradições, ou seja, será analisado o contraponto entre a espionagem estadunidense fundamentada na proteção de sua segurança pública e a violação da privacidade dos dados pessoais dos brasileiros na Internet.

Por sua vez, os métodos de procedimento serão o histórico, o bibliográfico e o comparativo. 0 primeiro é necessário para verificar as consequências dos ataques terroristas de 11 de setembro de 2001 na segurança norte-americana e o posterior fortalecimento dos métodos de vigilância no combate ao terrorismo. O segundo procedimento visa esclarecer todos os conceitos presentes na pesquisa, utilizando para tanto o posicionamento jurídico-doutrinário de diferentes estudiosos sobre o tema. Por fim, buscando estabelecer um contraponto entre a proteção da segurança pública frente ao terrorismo e a privacidade de dados pessoais na Internet, de modo a analisar comparativamente a justificativa dos Estados Unidos da América para a espionagem e a defesa da privacidade dos brasileiros, utilizar-se-á o método comparativo.

Outrossim, verifica-se a relevância de tal estudo não só atualmente, em razão dos fatos relatados, mas também para que seja protegido um direito tão fundamental quanto a privacidade em um âmbito que vem ganhando cada vez mais importância para o Direito recentemente e exigindo amplos estudos na área das ciências sociais, qual seja, a proteção jurídica das pessoas na Internet. 


\title{
10 DIREITO FUNDAMENTAL À PRIVACIDADE DOS DADOS PESSOAIS NA INTERNET
}

Primeiramente, para que se possa compreender a proteção decorrente da inviolabilidade dos dados pessoais dos brasileiros na Internet, é necessário que se faça a distinção entre privacidade e intimidade. Embora pareçam termos sinônimos e sejam usados como tal, a diferença foi bem explicada pelo Tribunal Constitucional Alemão ao adotar a Teoria das Esferas.

\begin{abstract}
Exposta através do Tribunal Constitucional Federal Alemão, a teoria das esferas divide o direito à privacidade em camadas, as quais tornam a incisão externa cada vez mais restrita e em algumas delas impossível. A esfera privada é a primeira delas (Privatsphäre), compreendendo questões que o indivíduo deseja que sejam mantidas em resguardo, fora do conhecimento público; a camada seguinte é chamada de intimidade (Intimsphäre), nesta há uma maior confidencialidade, ou seja, somente aqueles possuidores de relações íntimas teriam acesso às informações. Finalizando a etapa mais restrita dentro da teoria é a do segredo (Gehermsphäre), concebendo os atributos mais profundos no âmago pessoal e sigiloso do ser humano. ${ }^{7}$
\end{abstract}

Assim, resta claro que a privacidade é gênero e a intimidade é espécie, o que enseja o uso do primeiro termo para uma compreensão mais abrangente da interferência estatal no âmbito privado. Sendo a noção de intimidade mais específica, denota-se que o estudo desta restringiria o tema ora analisado, uma vez que a privacidade abrange um número maior de situações que se deseja manter em segredo. ${ }^{8}$

Dessa forma, o conceito mais preciso a ser utilizado no presente estudo, conforme Pereira, seria o mais abrangente, qual seja, a privacidade, visto que é um termo castelhanizado da privacy norte-americana, direito amplo que aplica-se à proteção dos dados pessoais no âmbito virtual. 0 referido autor aduz que

A doutrina que se ocupa do estudo do Direito Informático costuma vincular a ideia de privacidade com a de proteção de dados pessoais tratados

\footnotetext{
${ }^{7}$ BOFF, Salete Oro; DIAS, Felipe de Veiga Dias. Direito à privacidade online: um sonho virtual ou uma realidade constitucionalmente possível?. In: ADOLFO, Luiz Gonzaga Silva (coord.). Direitos Fundamentais na Sociedade da Informação. Florianópolis: UFSC/GEDAI, 2012, p. 148-149.

${ }^{8}$ Ibidem, p. 149.

REDESG / Revista Direitos Emergentes na Sociedade Global - www.ufsm.br/redesg v. 3, n. 1, jan-jun/2014
} 
A ESPIONAGEM DOS ESTADOS UNIDOS DA AMÉRICA E A VIOLAÇÃO DA PRIVACIDADE DE DADOS PESSOAIS DOS BRASILEIROS NA INTERNET

eletronicamente. Nesta linha, entendemos inserir-se a opinião de Davara Rodríguez. Relacionando a proteção de dados pessoais com a informática (...) afirma o citado autor que o que se pretende proteger não é a intimidade e, sim, algo com maior profundidade que, em sua opinião, se 'ha castellanizado' como privacidade. Nosso posicionamento sobre a questão é o seguinte: (...) Vincular a privacidade (privacy) à proteção dos dados pessoais frente ao avanço (e hipotética ameaça) da informática, também seria cerceá-la em seu âmbito de alcance e proteção, tendo em vista que a proteção de dados pessoais frente às novas tecnologias é tão-somente uma das muitas hipóteses que estão protegidas pela privacy norte-americana. Por tudo isso, entendemos que a melhor solução seria aceitar o uso do termo 'privacidade' para referir-se à privacy. ${ }^{9}$

Desse modo, a proteção da intimidade dá-se tanto no sentido de evitar que a pessoa sofra interferências em seu âmbito íntimo, essencial para que se desenvolva como ser humano, quanto no objetivo de conceder a esta a liberdade de optar em quais momentos e condições deseja expor sua vida pessoal. Trata-se, portanto, de um direito negativo na primeira circunstância e de um direito positivo na segunda. ${ }^{10}$

Outrossim, é imprescindível analisar o conceito de dados pessoais para melhor compreensão do presente trabalho. Sendo omissa a legislação pátria quanto ao tratamento destes, faz-se necessário recorrer à Lei nº 67/98 de Portugal ${ }^{11}$, que bem conceitua tal termo. Conforme aduz Catarina Sarmento e Castro, tal lei “deu uma noção de dados pessoais, entendendo-se como tal qualquer informação, de qualquer natureza e independentemente do respectivo suporte, incluindo som e imagem, relativa a uma pessoa singular identificada ou identificável". ${ }^{12}$

No que tange à proteção da privacidade dos dados pessoais na Internet, considerando que a rede mundial interliga diversos atores internacionais, é importante contextualizá-la com o surgimento do fenômeno mundial denominado globalização. A globalização e o consequente estreitamento das fronteiras entre as nações começaram a surgir durante o século XX, com a utilização dos meios de comunicação em massa, principalmente a partir das evoluções tecnológicas dos anos setenta, levando a uma maior preocupação com a privacidade das pessoas

\footnotetext{
${ }^{9}$ PEREIRA, Marcelo Cardoso. Direito à intimidade na internet. 1. ed., 3. tir. Curitiba: Juruá, 2005, p. 123125.

${ }^{10}$ Ibidem, p. 130.

${ }^{11}$ COMISSÃO NACIONAL DE PROTECÇÃO DE DADOS. Lei da protecção de dados pessoais. Disponível em: <http://www.cnpd.pt/bin/legis/nacional/lei_6798.htm>. Acesso em: 04 dez. 2014.

12 CASTRO, Catarina Sarmento e. Direito da informática, privacidade e dados pessoais. Coimbra: Ed. Almedina, 2005, p. 70-71.

REDESG / Revista Direitos Emergentes na Sociedade Global - www.ufsm.br/redesg v. 3, n. 1, jan-jun/2014
} 
A ESPIONAGEM DOS ESTADOS UNIDOS DA AMÉRICA E A VIOLAÇÃO DA PRIVACIDADE DE DADOS PESSOAIS DOS BRASILEIROS NA INTERNET

MÁRCIO DE SOUZA BERNARDES E RODRIGO AGUIAR DA SILVA

neste novo aspecto social, qual seja, o do avanço da informática e o consequente descontrole na circulação de dados entre diversos Estados, particulares e empresas privadas. ${ }^{13}$

Existe, portanto, um novo cenário socialmente construído pela globalização onde a informação é essencial, sendo inclusive associado o poder a quem a detenha, conforme afirma Marcelo Cardoso Pereira:

Vivemos, atualmente, em uma sociedade em que, segundo a máxima, a
informação é poder, vale dizer, quanto mais informação mais poder. Fala-se,
então, de uma sociedade da informação, que para nós seria, em realidade, uma
sociedade dependente da informação, tendo em vista o grau de sociabilidade
humana e o nível de desenvolvimento tecnológico das comunicações hoje
existentes, fatores que facilitam substancialmente o intercâmbio de
informações. ${ }^{14}$

Sendo a sociedade da informação uma realidade atual, com a Internet conectando todos os países do planeta e disseminando a informação em tempo real, cria-se inclusive a expectativa por uma ciberdemocracia global, utilizando-se a rede virtual para uma maior ligação entre os Estados e indivíduos. ${ }^{15}$ No entanto, mesmo que essa informatização da sociedade traga benefícios, também pode gerar o interesse do Estado para evitar decisões políticas que afetem o governo, devendo-se proteger ainda mais os dados pessoais que podem ser acessados e, muitas vezes, controlados através da Internet. Dessa forma, evita-se a obtenção de vantagens para quem violá-los e protege-se a privacidade de todos os usuários do âmbito virtual, para que não ocorram graves consequências como as decorrentes da espionagem estadunidense em relação à soberania e aos direitos humanos fundamentais na rede cibernética.

Segundo Paesani, os riscos existentes para quem utiliza este meio de comunicação virtual “conduzem ao reconhecimento de um direito à 'autodeterminação informática' ou à 'privacidade informática', que devem ser incluídos entre os direitos fundamentais". ${ }^{16}$ Esta proteção à privacidade dos dados pessoais na Internet é de extrema relevância para o Direito

\footnotetext{
${ }^{13}$ RUARO, Regina Linden; RODRIGUEZ, Daniel Piñeiro. Nada a esconder? O direito à proteção de dados frente a medidas de segurança pública e intervenção estatal. Disponível em

<http://www.ambitojuridico.com.br/site/index.php?n_link=revista_artigos_leitura\&tartigo_id=9542\&revist a_caderno=4>. Acesso em: 09 set. 2013.

${ }^{14}$ PEREIRA, Marcelo Cardoso. Direito à intimidade na internet. 1. ed., 3. tir. Curitiba: Juruá, 2005, p. 141.

${ }^{15}$ LEMOS, André; LÉVY, Pierre. 0 futuro da internet: em direção a uma ciberdemocracia planetária. São Paulo: Paulus, 2010, p. 23.

${ }^{16}$ PAESANI, Liliana Minardi. Direito e Internet: liberdade de informação, privacidade e responsabilidade civil. 3. ed. São Paulo: Atlas, 2006, p. 53.
}

REDESG / Revista Direitos Emergentes na Sociedade Global - www.ufsm.br/redesg v. 3, n. 1, jan-jun/2014 
A ESPIONAGEM DOS ESTADOS UNIDOS DA AMÉRICA E A VIOLAÇÃO DA PRIVACIDADE DE DADOS PESSOAIS DOS BRASILEIROS NA INTERNET

MÁRCIO DE SOUZA BERNARDES E RODRIGO AGUIAR DA SILVA

atualmente, diante da evolução das novas tecnologias e sua interferência na vida privada dos indivíduos, evidenciada na conduta de órgãos de vigilância do governo estadunidense, pois, conforme a doutrinadora acima citada, a tecnologia "tem contribuído para um estreitamento crescente do circuito privado, na medida em que possibilita, até a longa distância, a penetração na intimidade da pessoa". ${ }^{17}$

Ademais, Danilo Doneda afirma que a tutela da privacidade na sociedade informacional não deve ser analisada apenas sob uma ótica negativa visando o isolamento da pessoa, mas sim compreendida como uma materialização da esfera privada, respeitando a dignidade da vida humana. ${ }^{18}$

Não bastasse o direito específico à autodeterminação informativa dos dados pessoais, reconhecido pela melhor doutrina, é consolidada na Constituição Federal brasileira, genericamente, a inviolabilidade da intimidade e da vida privada das pessoas, bem como a inviolabilidade do sigilo de dados, previstos no artigo $5^{\circ}$ da Carta Magna, incisos X e XII, respectivamente, entre o rol de direitos fundamentais constitucionalmente assegurados ${ }^{19}$. Nesse sentido, "tomando-se a Internet no contexto da sociedade da informação, entende-se que o núcleo ético-jurídico das relações humano-virtuais é a Constituição e toda sua carga axiológica, regulando o meio ambiente real e digital". ${ }^{20}$

Desse modo, denota-se uma proteção à privacidade dos dados pessoais tanto no âmbito interno brasileiro, com a concomitância dos incisos X e XII do artigo $5^{\circ}$ da Constituição Federal, quanto no âmbito externo, com a celebração de tratados e convenções internacionais, nos quais se destaca a Declaração Universal dos Direitos do Homem de 1948, que protegem os direitos humanos, entre eles o direito à autodeterminação informativa. Assim entende Tercio Sampaio Ferraz Júnior, segundo o qual

No direito à privacidade, o objeto é, sinteticamente, a integridade moral do sujeito. Tanto conteúdo quanto objeto são muito claros no art. 12 da Declaração Universal dos Direitos do Homem de 1948, em que se lê: "Ninguém sofrerá

\footnotetext{
${ }^{17}$ PAESANI, Liliana Minardi. Direito e Internet: liberdade de informação, privacidade e responsabilidade civil. 3. ed. São Paulo: Atlas, 2006, p. 53.

${ }^{18}$ DONEDA, Danilo. Da privacidade à proteção de dados pessoais. Rio de Janeiro: Renovar, 2006, p. 14.

19 PORTAL PLANALTO. Constituição da República Federativa do Brasil de 1988. Disponível em < http://www.planalto.gov.br/ccivil_03/constituicao/constituicao.htm>. Acesso em 04 nov. 2013.

${ }^{20}$ DIAS, Felipe da Veiga; REIS, Jorge Renato dos. A Constituição como suporte ético às relações humanovirtuais: contributos da hermenêutica jurídica para o estabelecimento de fundamentos axiológicos no contexto da sociedade da informação. In: BOFF, Salete Oro; BORTOLANZA, Guilherme. Direitos Fundamentais e Novas Tecnologias. Florianópolis: Conceito Editorial, 2012, p. 39.

REDESG / Revista Direitos Emergentes na Sociedade Global - www.ufsm.br/redesg v. 3, n. 1, jan-jun/2014
} 
A ESPIONAGEM DOS ESTADOS UNIDOS DA AMÉRICA E A VIOLAÇÃO DA PRIVACIDADE DE DADOS PESSOAIS DOS BRASILEIROS NA INTERNET

MÁRCIO DE SOUZA BERNARDES E RODRIGO AGUIAR DA SILVA

intromissões arbitrárias na sua vida privada, na sua família, no seu domicilio ou na sua correspondência, nem ataques à sua honra e reputação. (...) 0 sigilo, no inciso XII do art. $5^{\circ}$, está referido à comunicação, no interesse da defesa da privacidade. 0 que fere a liberdade de omitir pensamento é, pois, entrar na comunicação alheia, fazendo com que o que devia ficar entre sujeitos que se comunicam privadamente passe ilegitimamente ao domínio de um terceiro (...) se alguém entra nesta transmissão, como um terceiro que nada tem a ver com a relação comunicativa, ou por ato próprio ou porque uma das partes the cede o acesso indevidamente, estará violado o sigilo de dados. ${ }^{21}$

$\mathrm{Na}$ mesma acepção de pensamento, entende Wachowicz que há uma estreita relação entre os princípios internacionais relativos aos direitos humanos e os direitos fundamentais constitucionalmente assegurados em cada país, sendo que estes se moldam de acordo com a recepção àqueles. ${ }^{22}$

Diante de tudo isso, sendo a privacidade dos dados pessoais na Internet um direito humano fundamental protegido tanto no âmbito nacional quanto no internacional, é imprescindível analisar a justificativa dada pelos Estados Unidos da América como fundamento para a espionagem cibernética realizada.

\section{A ESPIONAGEM CIBERNÉTICA ESTADUNIDENSE NO ÂMBITO BRASILEIRO}

Como resposta às revelações de Edward Snowden, o governo estadunidense justificou a espionagem como estratégia dos órgãos de inteligência em combate ao terrorismo e em prol da segurança pública de seus cidadãos ${ }^{23}$. Destarte, foram as atrocidades terroristas cometidas em 11 de setembro de 2001, com os atentados contra as torres gêmeas do World Trade Center e o Pentágono, que originaram a ira do governo de George W. Bush, trazendo como consequência

\footnotetext{
${ }^{21}$ FERRAZ JR., Tércio Sampaio. Sigilo de dados: o Direito à privacidade e os limites à função fiscalizadora do Estado. Disponível em: <http://www.terciosampaioferrazjr.com.br/?q=/publicacoes-cientificas/28>. Acesso em: 03 set. 2013.

${ }_{22}$ WACHOWICZ, Marcos. A sociedade da informação e direitos humanos. In: RIBEIRO, Maria de Fátima (coord.). Direito internacional dos direitos humanos: estudos em homenagem à Prof ${ }^{a}$. Flávia Piovesan. 3. tir. Curitiba: Juruá, 2006.

${ }^{23} \mathrm{O}$ GLOBO. EUA justificam espionagem por ameaças terroristas. Disponivel em: <http://oglobo.globo.com/mundo/eua-justificam-espionagem-por-ameacas-terroristas-8869281>. Acesso em: 14 jul. 2013.

REDESG / Revista Direitos Emergentes na Sociedade Global - www.ufsm.br/redesg v. 3, n. 1, jan-jun/2014
} 
A ESPIONAGEM DOS ESTADOS UNIDOS DA AMÉRICA E A VIOLAÇÃO DA PRIVACIDADE DE DADOS PESSOAIS DOS BRASILEIROS NA INTERNET

MÁRCIO DE SOUZA BERNARDES E RODRIGO AGUIAR DA SILVA

uma nova vontade política de invasão na esfera privada dos cidadãos com a finalidade de prevenção a novos ataques terroristas. ${ }^{24}$

Visando não ser mais surpreendido por novos atentados que ocasionassem um grande número de civis mortos tal como ocorreu em 11 de setembro de 2001, o governo estadunidense e seus órgãos de inteligência adotaram a estratégia de uma vigilância global, utilizando para tanto o âmbito virtual através da estrutura da Internet. ${ }^{25}$ De modo a concretizar esta nova postura governamental, os Estados Unidos da América editaram a Lei Patriótica, denominada USA Patriot Act, como bem explicam Ruaro e Rodríguez ao afirmarem que

Informações estatais e interesses de vigilância passaram a ser tema constante na pauta política dos principais países, após os atentados de 11 de setembro. Seus reflexos não são identificados somente nos Estados Unidos, mas também na Alemanha. Os conflitos entre a efetivação da segurança nacional, de um lado, e respeito à autodeterminação informativa dos indivíduos, do outro, foi sensivelmente aguçado a partir deste marco temporal. Nos Estados Unidos, há o famoso "Patriot Act" que, após o atentado de 11 de setembro, teve por objetivo atacar o terrorismo e o seu financiamento, aumentando as possibilidades de poder e controle estatal sobre imigrantes e estrangeiros. Para tanto, proporcionou o aumento do poder de agências do governo na interceptação telefones, e-mails, dados médicos, financeiros, etc., além de alterar muitas leis em relação à privacidade. ${ }^{26}$

Assim, verifica-se que os Estados Unidos da América buscaram legitimar “democraticamente" a espionagem com a edição da referida lei, aproveitando o medo da população após os atentados, de modo a elevar o controle governamental sobre a privacidade dos cidadãos com a justificativa de garantir a segurança pública destes. Em consequência à insegurança generalizada e diante do desejo de inserção tecnológica, o povo estadunidense iniciou um fornecimento espontâneo de informações pessoais ao Estado. No entanto, tal concessão deve ser analisada com cuidado, conforme afirmam Gediel e Corrêa, pois há certa

\footnotetext{
${ }^{24}$ HARDING, Luke, Os arquivos Snowden: a história secreta do homem mais procurado do mundo. Rio de Janeiro: LeYa, 2014, p. 73.

${ }_{25}$ PEREIRA, Marcelo Cardoso. Direito à intimidade na internet. 1. ed., 3. tir. Curitiba: Juruá, 2005, p. 166.

${ }^{26}$ RUARO, Regina Linden; RODRIGUEZ, Daniel Piñeiro, Nada a esconder? 0 direito à proteção de dados frente a medidas de segurança pública e intervenção estatal. Disponível em

<http://www.ambitojuridico.com.br/site/index.php?n_link=revista_artigos_leitura\&tartigo_id=9542\&revist a_caderno=4>. Acesso em: 09 set. 2013.

REDESG / Revista Direitos Emergentes na Sociedade Global - www.ufsm.br/redesg v. 3, n. 1, jan-jun/2014
} 
A ESPIONAGEM DOS ESTADOS UNIDOS DA AMÉRICA E A VIOLAÇÃO DA PRIVACIDADE DE DADOS PESSOAIS DOS BRASILEIROS NA INTERNET

MÁRCIO DE SOUZA BERNARDES E RODRIGO AGUIAR DA SILVA

dubiedade no momento em que o indivíduo requer a proteção dos direitos fundamentais, mas, por outro lado, abandona-os prontamente como garantia à sua segurança. ${ }^{27}$

Considerando a privacidade como direito fundamental, de acordo com o pensamento de Jorge Miranda, o fundamento da nova política estadunidense poderia ser considerado correto, afirmando este que "os direitos fundamentais estão necessariamente sujeitos a limites, ainda que de natureza e grau muito diversos. Não há liberdades absolutas; elas aparecem, pelo menos, limitadas pela necessidade de assegurar as liberdades dos outros". ${ }^{28}$ Seguindo a mesma linha de raciocínio, Paesani aduz que "podem ser impostos limites à normal esfera de privacidade até contra a vontade do indivíduo, mas em correspondência a sua posição na sociedade, se for de relevância pública". ${ }^{29}$ Desse modo, a proteção da liberdade de todos os cidadãos perante a ameaça terrorista permitiria uma restrição na vida privada do indivíduo, analisando-se sob a ótica do bem comum da população em sobreposição à liberdade individual.

No mesmo sentido, Maria Cláudia Cachapuz entende como necessários certos sacrifícios quanto às liberdades individuais para a efetiva realização do bem-estar geral da população, ao afirmar que

[...] como se exige um sacrifício no âmbito privado - em relação às necessidades ndividuais - para justificar a obtenção de iguais possibilidades de felicidade ou de bem-estar no âmbito público, é imprescindível analisar que forma se passa a exigir uma proporcional medida de sacrifício a todos e a qualquer um para que possam viver, em liberdade, num espaço de interesses compartilhados.(...) 0 Direito, portanto, só atinge sua função efetiva quando, identificadas as liberdades individuais, consegue integrá-las de forma a compatibilizá-las no agir social, gerando estabilidade aos relacionamentos no âmbito público. ${ }^{30}$

Ademais, José Adércio Leite Sampaio acredita que para combater o terrorismo com igualdade de condições, há que se flexibilizar certas normas jurídicas, mesmo que sejam

\footnotetext{
${ }^{27}$ GEDIEL, J. A. P.; CORRÊA, A. E. Proteção jurídica de dados pessoais: a intimidade sitiada entre o Estado e o mercado. Revista da Faculdade de Direito - UFPR, Curitiba, n. 47, 2008.

${ }^{28}$ MIRANDA, Jorge. Os direitos fundamentais perante o Terrorismo. In: BRANT, Leonardo Nemer Caldeira. Terrorismo e Direito: os impactos do terrorismo na comunidade internacional e no Brasil. Rio de Janeiro: Forense, 2003, p. 57.

${ }^{29}$ PAESANI, Liliana Minardi. Direito e Internet: liberdade de informação, privacidade e responsabilidade civil. 3. ed. São Paulo: Atlas, 2006, p. 49.

${ }^{30}$ CACHAPUZ, Maria Cláudia, Intimidade e vida privada no novo Código Civil Brasileiro: uma leitura orientada no discurso jurídico. Porto Alegre: Sergio Antonio Fabris Ed., 2006, p. 45-46.

REDESG / Revista Direitos Emergentes na Sociedade Global - www.ufsm.br/redesg v. 3, n. 1, jan-jun/2014
} 
A ESPIONAGEM DOS ESTADOS UNIDOS DA AMÉRICA E A VIOLAÇÃO DA PRIVACIDADE DE DADOS PESSOAIS DOS BRASILEIROS NA INTERNET

MÁRCIO DE SOUZA BERNARDES E RODRIGO AGUIAR DA SILVA

garantias constitucionais, de modo a elencar a segurança pública e a integridade física dos indivíduos como prioridade sobre aquelas. ${ }^{31}$

No entanto, diante do crescente controle dos Estados Unidos da América perante a privacidade dos indivíduos no âmbito virtual, considerando a importância da obtenção de dados na sociedade informacional, verifica-se que tal Estado passou a deter um poder descomunal frente aos seus cidadãos e também no plano internacional, visto que na sociedade atual impera a máxima de que “informação é poder". Dessa forma, permite-se falar até mesmo em uma dominação tecnológica dos Estados Unidos da América em relação aos países menos desenvolvidos como o Brasil, ainda mais após o vazamento da informação de que a NSA espionava a principal empresa estatal brasileira, uma vez que

[...] existe um amplo registro de informações sobre a situação de países menos favorecidos economicamente por parte de países com melhor desenvolvimento [...] quando a recíproca não encontra correspondência no fluxo de informações trabalhado em países com desenvolvimento tecnológico mais limitado. [...] É uma disparidade de tratamento capaz de auxiliar a manutenção de uma dominação tecnológica por agentes interessados no controle do processo de transferência de informações, distanciando os países menos favorecidos economicamente de uma participação igualitária no rentável mercado internacional de fluxo de informações. ${ }^{32}$

Diante do exposto, frente a uma possível afronta à soberania brasileira decorrente da violação dos dados pessoais de seus cidadãos por órgãos de inteligência de um Estado estrangeiro, reputa-se necessário analisar o modo como a globalização enfraqueceu o Estado no plano internacional, afetando diretamente a soberania de cada nação, sobretudo no contexto da sociedade informacional.

$\mathrm{Na}$ medida em que a espionagem ultrapassou o âmbito nacional dos Estados Unidos da América e atingiu cidadãos de diversos outros países, passou a receber críticas internacionais pelos atos de vigilância. No que tange ao governo brasileiro, a presidente Dilma Rousseff condenou publicamente a espionagem estadunidense, especialmente em seu discurso na abertura da $68^{\mathrm{a}}$ Assembleia-Geral das Nações Unidas, no qual afirma que este é um caso de

\footnotetext{
${ }^{31}$ SAMPAIO, José Adércio Leite. Constituição e Terror - uma visão parcial do fenômeno terrorista. In: BRANT, Leonardo Nemer Caldeira. Terrorismo e Direito: os impactos do terrorismo na comunidade internacional e no Brasil. Rio de Janeiro: Forense, 2003, p. 160.

32 CACHAPUZ, Maria Cláudia, Intimidade e vida privada no novo Código Civil Brasileiro: uma leitura orientada no discurso jurídico. Porto Alegre: Sergio Antonio Fabris Ed., 2006, p. 273-274.

REDESG / Revista Direitos Emergentes na Sociedade Global - www.ufsm.br/redesg v. 3, n. 1, jan-jun/2014
} 
A ESPIONAGEM DOS ESTADOS UNIDOS DA AMÉRICA E A VIOLAÇÃO DA PRIVACIDADE DE DADOS PESSOAIS DOS BRASILEIROS NA INTERNET

MÁRCIO DE SOUZA BERNARDES E RODRIGO AGUIAR DA SILVA

grave violação dos direitos humanos e das liberdades civis, que afronta a soberania brasileira ${ }^{33}$. Alegou, ainda, que “jamais pode uma soberania firmar-se em detrimento de outra soberania. Jamais pode o direito à segurança dos cidadãos de um país ser garantido mediante a violação de direitos humanos fundamentais dos cidadãos de outros países"34.

Hodiernamente, no entanto, a soberania de um Estado vem sendo flexibilizada em um contexto internacional, diante dos acordos e convenções celebrados entre vários países e também em consequência da globalização, definida por Matias como

[...] a maior integração dos países e das pessoas do mundo, causada pela enorme redução de custos de transporte e comunicação, e pela derrubada das barreiras artificiais ao fluxo de bens, serviços, capital, conhecimento e - em menor extensão - pessoas através das fronteiras. ${ }^{35}$

Diante disso, avista-se entre as principais causas da globalização a grande facilidade em utilizar a comunicação para conectar mundialmente as pessoas, levando a uma quebra das barreiras antes existentes e criando uma humanidade sem fronteiras. Nesse sentido, outro fator é de suma importância para que se possa entender um novo conceito de soberania, qual seja, a existência do ciberespaço, pois "a soberania sempre foi identificada com a noção de território, relacionando-se com o controle pelo Estado do espaço físico e das pessoas localizadas em suas fronteiras. Em contraste, o ciberespaço não tem limites territoriais". ${ }^{36}$

Assim, o âmbito no qual a Internet é utilizada para propagar a comunicação em nível extraterritorial afeta a soberania estatal, ante a dificuldade em normatizar e fiscalizar o que está acontecendo virtualmente devido à extrema rapidez com que as informações são divulgadas. Desse modo, verifica-se que "a existência do ciberespaço contribui para a perda de efetividade do poder estatal, pois, ao não conseguir regular as atividades na rede, o Estado diminui seu controle sobre seu território". ${ }^{37}$ Diante da perda do predomínio estatal perante os

\footnotetext{
${ }^{33} \mathrm{O}$ PAÍS ONLINE. Dilma diz que espionagem dos EUA é grave violação dos direitos humanos. Disponível em: <http://www.opais.co.mz/index.php/internacional/56-internacional/27246-dilma-diz-queespionagem-dos-eua-e-grave-violacao-dos-direitos-humanos-macia.html>. Acesso em: 21 out. 2013.

${ }^{34} \mathrm{G} 1$. Dilma diz na ONU que espionagem fere soberania e direito internacional. Disponível em: <http://g1.globo.com/mundo/noticia/2013/09/dilma-diz-na-onu-que-espionagem-fere-soberania-edireito-internacional.html>. Acesso em: 25 set. 2013.

${ }^{35}$ MATIAS, Eduardo Felipe Pérez. A humanidade e suas fronteiras: do Estado soberano à sociedade global. São Paulo: Paz e Terra, 2005, p. 105.

${ }^{36}$ MATIAS, Eduardo Felipe Pérez. A humanidade e suas fronteiras: do Estado soberano à sociedade global. São Paulo: Paz e Terra, 2005, p. 159.

${ }^{37}$ Ibidem, p. 158.

REDESG / Revista Direitos Emergentes na Sociedade Global - www.ufsm.br/redesg v. 3, n. 1, jan-jun/2014
} 
A ESPIONAGEM DOS ESTADOS UNIDOS DA AMÉRICA E A VIOLAÇÃO DA PRIVACIDADE DE DADOS PESSOAIS DOS BRASILEIROS NA INTERNET

MÁRCIO DE SOUZA BERNARDES E RODRIGO AGUIAR DA SILVA

demais atores internacionais no ciberespaço com o fenômeno da globalização, deve-se atentar que "ao inviabilizar o exercício da soberania, a globalização incontrolada engendra o risco de anular a cidadania e, com ela, os direitos humanos". ${ }^{38}$

Portanto, a inexistência de fronteiras no que tange ao ciberespaço revela-se um complexo óbice na regulamentação do uso desse ambiente e no combate aos crimes virtuais por um único Estado em defesa de sua soberania, solução que poderia ser obtida através da cooperação internacional entre Estados. ${ }^{39}$ Nesse contexto, é de suma importância que se estabeleça uma comparação entre a relevância jurídica da proteção da segurança pública norteamericana e a magnitude do direito à privacidade dos dados pessoais na Internet.

\section{O CONFLITO ENTRE A DEFESA DA SEgURANÇA PÚBLICA NORTE- AMERICANA E A PRIVACIDADE DOS BRASILEIROS NA INTERNET}

Ao confrontar a captação estatal de dados pessoais na Internet em prol da segurança pública com a violação do direito fundamental à privacidade, percebem-se duas concepções de grande relevância jurídica que se chocam entre si e aparentemente não convivem em harmonia, sendo imprescindível, portanto que se analise qual delas tem mais importância e, consequentemente, deve prevalecer sobre a outra.

Pretende-se analisar, portanto, se a espionagem dos Estados Unidos da América, amparada pela proteção da segurança pública em combate ao terrorismo, é motivo suficiente para que se viole a privacidade dos dados pessoais de brasileiros na Internet, direito fundamental da pessoa humana assegurado tanto constitucionalmente quanto internacionalmente, como já demonstrado. Marcelo Cardoso Pereira adota uma posição intermediária, acreditando que não deve haver uma proibição ao Estado de infiltrar-se na vida privada do indivíduo, desde que a interferência não seja vista como regra geral. Segundo o autor,

\footnotetext{
${ }^{38}$ ALVES, José Augusto Lindgren. Cidadania, direitos humanos e globalização. In: PIOVESAN, Flávia (coord.). Direitos humanos, globalização econômica e integração regional: desafios do direito constitucional internacional. São Paulo: Max Limonad, 2002, p. 77.

${ }^{39}$ MATIAS, Eduardo Felipe Pérez, op. cit., p. 165.

REDESG / Revista Direitos Emergentes na Sociedade Global - www.ufsm.br/redesg v. 3, n. 1, jan-jun/2014
} 
A ESPIONAGEM DOS ESTADOS UNIDOS DA AMÉRICA E A VIOLAÇÃO DA PRIVACIDADE DE DADOS PESSOAIS DOS BRASILEIROS NA INTERNET

MÁRCIO DE SOUZA BERNARDES E RODRIGO AGUIAR DA SILVA

Afirma Herrero-Tejedor que o Estado, para desempenhar suas funções de segurança, exige dos cidadãos dados relativos a estes, os quais podem ser, e na maioria das vezes o são, dados que revelam aspectos da vida privada das pessoas. [...] Mais contundente é a opinião de Rebollo Delgado. Segundo este autor, a teoria del seguismo, que consiste na atividade do Estado de exigir determinadas informações ou dados pessoais dos cidadãos para cumprir com sua função de garantir-lhes um nível de segurança satisfatório, menoscaba o direito à intimidade dos administrados, tendo em vista que estabelece um regime de ditadura do social. Em nosso entendimento, a melhor solução seria encontrar uma posição intermediária. Reconhecemos que a máquina estatal não possui, em determinadas situações, a necessidade de solicitar dados relativos à intimidade dos administrados. Tampouco é correto afirmar que, como regra geral, exista uma proibição ao Estado que o impeça solicitar dados ou informações dos cidadãos, ainda que [...] relativas a determinados aspectos da esfera privada. ${ }^{40}$

No entanto, com relação à espionagem eletrônica que possa ser realizada por algum Estado, o referido doutrinador é categórico ao afirmar que há uma violação da privacidade de dados pessoais, analisando que

\begin{abstract}
Os países que mantêm sistemas de vigilância eletrônica, e isso quando o admitem, costumam justificar sua existência e funcionamento com base no combate ao terrorismo e em outras condutas ilícitas que se levam a cabo mediante a utilização de novas tecnologias, entre as quais está, obviamente e com destaque, a Internet. E'dizer, justificam a existência desses sistemas como uma forma de proporcionar e garantir a segurança pública. Ainda que possa parecer uma louvável justificativa, esses sistemas de vigilância eletrônica atentam contra o direito à intimidade dos cidadãos em geral e, portanto, contra o direito à intimidade dos usuários da Rede. ${ }^{41}$
\end{abstract}

Destarte, verifica-se que a interferência estatal na esfera privada do indivíduo é legalmente permitida, desde que seja realizada com caráter excepcional e, impreterivelmente, com a autorização deste. No âmbito virtual, contudo, o Estado muitas vezes se aproveita das facilidades na utilização da Rede e do anonimato permitido por esta, ocorrendo vigilância sem a devida ciência daquele que teve a privacidade limitada.

Tal facilitação da penetração na privacidade por intermédio da Internet, conforme Salete Oro Boff e Felipe de Veiga Dias, gera uma falsa noção de que o ambiente virtual seria desprovido de legalidade, com absoluta liberdade. Porém, como bem salientam os autores, este

\footnotetext{
${ }^{40}$ PEREIRA, Marcelo Cardoso, Direito à intimidade na internet. 1. ed., 3. tir. Curitiba: Juruá, 2005, p. 142.

${ }^{41}$ Ibidem, p. 167.

REDESG / Revista Direitos Emergentes na Sociedade Global - www.ufsm.br/redesg v. 3, n. 1, jan-jun/2014
} 
A ESPIONAGEM DOS ESTADOS UNIDOS DA AMÉRICA E A VIOLAÇÃO DA PRIVACIDADE DE DADOS PESSOAIS DOS BRASILEIROS NA INTERNET

espaço nada mais é do que outro local em que há troca de relações pessoais, não havendo óbice algum para a proteção do direito à privacidade. ${ }^{42}$

Considerando isso, é necessário verificar se o indivíduo concorda com a interferência governamental para proteger sua segurança, o que parece inviável diante de uma espionagem na qual a privacidade de uma pessoa é violada de maneira sigilosa, auxiliada pela facilidade na obtenção de informações com a utilização das novas tecnologias, principalmente da Internet.

Importante salientar que, diante das ações sorrateiras que levaram o governo dos Estados Unidos da América a uma vigilância em massa sem precedentes, Edward Snowden fez uma interessante e oportuna analogia da situação atual ao panóptico de Jeremy Bentham, filósofo do século XVIII. Este se referia a uma engenhosa prisão considerada ideal pelo seu formato circular, o qual permitia que seus guardas vigiassem os prisioneiros o tempo todo, sem a ciência destes de que estavam sendo observados. ${ }^{43}$

Diante disso, Paesani faz ressalvas a esta invasão estatal à privacidade, alegando que

\begin{abstract}
informações respeitantes à esfera íntima da vida privada podem ser consideras lícitas, quando justificadas por um legítimo interesse do sujeito que as recebe; trata-se de saber se o fim a que a informação serve tem maior valor que o interesse do sujeito ao qual se refere essa informação. (...) Outros limites à privacidade podem ser impostos, quando atingem interesses coletivos diferentes do direito à informação e de maior relevância numa avaliação conjunta do interesse geral. A predominância do interesse coletivo sobre o particular requer, em cada caso, a verificação do alcance respectivo, a fim de não se sacrificar indevidamente a pessoa. ${ }^{44^{3}}$
\end{abstract}

Assim, de acordo com a autora supracitada, verifica-se que a vigilância estatal com fulcro na segurança pública dos cidadãos não pode ser vista como uma justificativa ilimitada, visto que deve ser ponderado em cada caso a predominância do direito público sobre o privado para que não ocorram excessos. Prosseguindo em sua análise, Paesani faz mais um contraponto à permissão da violação da privacidade pela esfera estatal, argumentando que a interferência estatal na vida privada de alguém só deve ocorrer quando houver indícios suficientes de que a pessoa possa ameaçar a segurança pública. Nas palavras da referida doutrinadora,

\footnotetext{
${ }^{42}$ BOFF, Salete Oro; DIAS, Felipe de Veiga. Direito à privacidade online: um sonho virtual ou uma realidade constitucionalmente possível?. In: ADOLFO, Luiz Gonzaga Silva (coord.). Direitos Fundamentais na

Sociedade da Informação. Florianópolis: UFSC/GEDAI, 2012, p. 154-155.

${ }^{43}$ HARDING, Luke, Os arquivos Snowden: a história secreta do homem mais procurado do mundo. Rio de Janeiro: LeYa, 2014, p. 15.

${ }^{44}$ PAESANI, Liliana Minardi, Direito e Internet: liberdade de informação, privacidade e responsabilidade civil. 3. ed. São Paulo: Atlas, 2006, p. 48.

REDESG / Revista Direitos Emergentes na Sociedade Global - www.ufsm.br/redesg v. 3, n. 1, jan-jun/2014
} 
a crescente escalada de violência tem possibilitado ao Poder Público a captação de informações e dados privados por meio de métodos eletrônicos sofisticados. Entende a doutrina que, diante dos fins visados, é possível a ação interceptora, sacrificando-se os direitos individuais em prol do bem comum. Essas interferências estão legitimadas pelo sistema jurídico, em função da orientação que cabe ao Estado de conceder segurança a seus cidadãos. Entretanto, o perigo desses avanços pode conduzir a um domínio tecnológico estatal com consequências sociais e políticas imprevisíveis, a menos que para sua utilização existam provas contundentes da participação da pessoa visada. ${ }^{45}$

As referidas consequências sociais e políticas negativas que podem ocorrer diante da ação interceptora do Estado no núcleo de informações privadas dos cidadãos decorrem da já mencionada sociedade informacional, visto que hodiernamente a informação é considerada um meio de alcance ao poder. Considerando que a obtenção de dados pessoais na Internet tornou-se uma prática comum do governo norte-americano, salienta-se mais uma vez o perigo acerca de um possível domínio tecnológico dos Estados Unidos da América, não apenas sobre os habitantes de seu território, mas também sobre as demais nações e seus respectivos cidadãos.

Da mesma forma, Augusto Tavares Rosa Marcacini pensa que "quem detiver um tal mecanismo central, para decifrar mensagens alheias, cumulará em suas mãos um poder descomunal e por demais perigoso para a ordem democrática. Afinal, na sociedade moderna, informação é poder". ${ }^{46}$

Como bem destaca Luke Harding, a intenção original da NSA de recolhimento da inteligência sobre o exterior havia sido afastada por um novo objetivo: a coleta de dados sobre todos, tanto de indivíduos dos EUA quanto de outros países. ${ }^{47}$ Dessa forma, "a missão crucial da NSA era zelar pela segurança nacional. Ao menos essa era a ideia. Mas, ao final de 2013, parecia que as operações de coleta de informações da agência tinham um objetivo muito mais simples poder global". 48

No entanto, mesmo que atuando apenas no âmbito interno dos Estados Unidos da América, os órgãos de inteligência do governo norte-americano não podem intrometer-se de tal modo na vida privada. Há uma limitação pela quarta emenda da Constituição dos EUA que proíbe

\footnotetext{
${ }^{45}$ Ibidem, p. 56.

${ }^{46}$ MARCACINI, Augusto Tavares Rosa. Direito e informática: uma abordagem jurídica sobre a criptografia. Rio de Janeiro: Forense, 2002, p. 125.

${ }^{47}$ HARDING, Luke. Os arquivos Snowden: a história secreta do homem mais procurado do mundo. Rio de Janeiro: LeYa, 2014, p. 11.

${ }^{48}$ Ibidem, p. 220.

REDESG / Revista Direitos Emergentes na Sociedade Global - www.ufsm.br/redesg v. 3, n. 1, jan-jun/2014
} 
A ESPIONAGEM DOS ESTADOS UNIDOS DA AMÉRICA E A VIOLAÇÃO DA PRIVACIDADE DE DADOS PESSOAIS DOS BRASILEIROS NA INTERNET

MÁRCIO DE SOUZA BERNARDES E RODRIGO AGUIAR DA SILVA

buscas e apreensões sem motivação, sendo que a interceptação de informações é legal apenas contra um sujeito específico e tão somente quando houver probabilidade de autoria criminosa por este, sob autorização de mandado judicial. ${ }^{49}$ Sendo assim, verifica-se que a vigilância governamental denunciada por Edward Snowden revela-se uma verdadeira afronta à própria Constituição dos Estados Unidos da América, uma vez que captou informações de maneira sigilosa e indiscriminadamente.

No que tange à política externa de combate ao terrorismo, pode-se afirmar que enseja uma atuação coordenada entre os diversos atores internacionais, de modo que a ação de um ente não se sobreponha à soberania de outro. Jorge Mascarenhas Lasmar entende que há um controle mútuo entre os Estados frente aos costumes e normas do Direito Internacional, motivo pelo qual não há plena liberdade na atuação de um Estado em combate ao terrorismo, limitando-se em razão da soberania dos entes públicos no âmbito internacional. ${ }^{50}$

Por sua vez, Alessandra Mendes Spalding acredita que as leis norte-americanas antiterroristas afetam não só o direito nos Estados Unidos da América, mas também o direito internacional, alertando que “o que não se pode admitir é que, em busca de atender a pretensões imediatistas, os governantes dos Estados Unidos olvidem-se da existência de normas protetoras dos direitos humanos". ${ }^{51}$

À vista disso, no caso em tela a espionagem dos Estados Unidos da América não deve ser repudiada apenas pelos países que tiveram sua soberania afrontada por esta, entre eles o Brasil, mas também por toda a comunidade internacional, em virtude da ampla abrangência do ciberespaço e pela gravidade da violação de direitos humanos. De acordo com Jorge Miranda,

Os Estados Unidos - postos à prova pelos atentados de 11 de setembro e que receberam tantas demonstrações de solidariedade de todos os continentes deveriam ser os primeiros a compreender que sem a cooperação internacional nada de sólido e duradouro é possível [...]. O terrorismo globalizado não diz respeito somente a este ou àquele Estado, por mais poderoso ou simultaneamente - mais vulnerável que seja. Diz respeito a toda a comunidade internacional; é ela que também é ofendida. Por isso, só pode ser vencido a partir de instrumentos jurídicos desta mesma comunidade internacional. Por isso,

\footnotetext{
${ }^{49}$ Ibidem, p. 75.

${ }^{50}$ LASMAR, Jorge Mascarenhas. Terrorismo Internacional e Globalização: A reestruturação do sistema internacional. In: BRANT, Leonardo Nemer Caldeira. Terrorismo e Direito: os impactos do terrorismo na comunidade internacional e no Brasil. Rio de Janeiro: Forense, 2003, p. 437.

${ }^{51}$ SPALDING, Alessandra Mendes. As leis terroristas norte-americanas e os direitos humanos. In: RIBEIRO, Maria de Fátima (coord.). Direito internacional dos direitos humanos: estudos em homenagem à Profa . Flávia Piovesan. 3. tir. Curitiba: Juruá, 2006, p. 37.

REDESG / Revista Direitos Emergentes na Sociedade Global - www.ufsm.br/redesg v. 3, n. 1, jan-jun/2014
} 
A ESPIONAGEM DOS ESTADOS UNIDOS DA AMÉRICA E A VIOLAÇÃO DA PRIVACIDADE DE DADOS PESSOAIS DOS BRASILEIROS NA INTERNET

só pode ser vencido sem transigências com qualquer desrespeito ou degradação dos direitos fundamentais. ${ }^{52}$

Nesta senda, dada a relevância da Internet como meio de comunicação na sociedade informacional, bem como a predominância do fenômeno da globalização nas relações internacionais e o consequente aumento da liberdade na troca de informações entre os cidadãos de diferentes países, deve-se preservar cuidadosamente os direitos fundamentais que ficam mais expostos diante da facilidade de interferência na esfera íntima das pessoas. Como bem sustenta Têmis Limberger,

[...] a tutela dos direitos da pessoa deve ser compatibilizada com as exigências do mundo atual, que almeja a liberdade de informação e a livre circulação dos dados. Em última análise, a informática é algo que já se incorporou na vida quotidiana moderna. Hoje, não se vislumbra retrocesso. 0 desafio é como proteger os dados informatizados frente a uma sociedade e um mercado cada vez mais livres de fronteiras. A globalização pressupõe e propõe uma economia sem fronteiras e sem regulamentação. No entanto, não se pode desprezar anos de construção de direitos fundamentais. ${ }^{53}$

Desse modo, não podemos abdicar de nossa privacidade, principalmente em razão da sua natureza de direito humano fundamental, mesmo em face das novas tecnologias e meios de comunicação onde prevalece a exposição do âmago mais profundo dos seres humanos. Em que pese a gravidade da má utilização da Internet com o fim de interceptar dados pessoais, como no caso da espionagem em massa dos Estados Unidos da América, este instrumento de propagação da informação é de suma importância para a difusão do conhecimento no mundo atual em razão de sua instantaneidade.

Por conseguinte, verifica-se que o bom uso da Internet não pode ser afetado pelo medo da vigilância constante pelo Estado onde a pessoa vive, muito menos por entes e órgãos de um governo estrangeiro, a qual esta não está subordinada. A interferência estatal na privacidade pode levar até mesmo, em longo prazo, a uma depreciação em sua utilização, visando evitar a

\footnotetext{
${ }^{52}$ MIRANDA, Jorge, Os direitos fundamentais perante o Terrorismo. In: BRANT, Leonardo Nemer Caldeira. Terrorismo e Direito: os impactos do terrorismo na comunidade internacional e no Brasil. Rio de Janeiro: Forense, 2003, p. 68.

${ }^{53}$ LIMBERGER, Têmis. Direito e informática: o desafio de proteger os direitos do cidadão. In: SARLET, Ingo Wolfgang (coord.). Direitos fundamentais, informática e comunicação: algumas aproximações. Porto Alegre: Livraria do Advogado, 2007.
}

REDESG / Revista Direitos Emergentes na Sociedade Global - www.ufsm.br/redesg v. 3, n. 1, jan-jun/2014 
A ESPIONAGEM DOS ESTADOS UNIDOS DA AMÉRICA E A VIOLAÇÃO DA PRIVACIDADE DE DADOS PESSOAIS DOS BRASILEIROS NA INTERNET

MÁRCIO DE SOUZA BERNARDES E RODRIGO AGUIAR DA SILVA

violação no âmbito privado. Nesse sentido, Harding afirma que, como consequência da vigilância eletrônica em massa realizada pelos Estados Unidos da América,

[...] a revolução do computador pessoal, que transformou o modo de se comunicar, havia chegado a um impasse: aqueles que se preocupavam com a privacidade foram obrigados a retornar à era pré-internet. Máquinas de escrever, notas manuscritas e encontros às escondidas estavam de volta à moda. Certamente era apenas uma questão de tempo até o retorno do pombo-correio. ${ }^{54}$

As consequências possíveis oportunizam até mesmo uma breve analogia com um clássico da literatura, a aclamada obra 1984, de George Orwell. Publicada originariamente no ano de 1949, a história remetia ao então longínquo ano de 1984, onde a sociedade era refém de um sistema de opressão absoluta, materializado na figura simbólica do Big Brother, aquele que observava e controlava todos. O controle era realizado através das denominadas teletelas, objeto tecnológico posto em cada residência que permitia a vigilância secreta e contínua do governo ${ }^{55}$.

Dessa forma, é inevitável a comparação da teletela com o atual computador, sendo ambos vistos como instrumentos de vigilância pelo governo e também meios que violam drasticamente a liberdade de expressão do indivíduo e o direito fundamental à privacidade. Caminhando neste sentido, os Estados Unidos da América estariam levando a atual sociedade globalizada a um totalitarismo mundial, tal como George Orwell já havia imaginado.

$\mathrm{Na}$ seara internacional, por exemplo, iniciou-se um amplo estudo em busca de medidas protetivas que estabelecessem uma maior restrição à interferência estrangeira no que concerne aos dados nacionais. As nações afetadas pela vigilância dos Estados Unidos da América manifestaram-se com repúdio à situação denunciada por Edward Snowden, inclusive na

\footnotetext{
${ }^{54}$ HARDING, Luke. Os arquivos Snowden: a história secreta do homem mais procurado do mundo. Rio de Janeiro: LeYa, 2014, p. 229.

${ }^{55} \mathrm{Tal}$ instrumento de vigilância pode ser facilmente compreendido nas palavras do próprio autor, segundo o qual "a teletela recebia e transmitia simultaneamente. Todo som produzido por Winston que ultrapassasse o nível de um sussurro muito discreto seria captado por ela; mais: enquanto Winston permanecesse no campo de visão enquadrado pela placa de metal, além de ouvido também poderia ser visto. Claro, não havia como saber se você estava sendo observado num momento específico. Tentar adivinhar o sistema utilizado pela Polícia das Ideias para conectar-se a cada aparelho individual ou a frequência com que o fazia não passava de especulação. Era possível inclusive que ela controlasse todo mundo o tempo todo. Fosse como fosse, uma coisa era certa: tinha meios de conectar-se a seu aparelho sempre que quisesse. Você era obrigado a viver - e vivia, em decorrência do hábito transformado em instinto - acreditando que todo som que fizesse seria ouvido e, se a escuridão não fosse completa, todo movimento examinado meticulosamente" (ORWELL, 2009, p. 13).
}

REDESG / Revista Direitos Emergentes na Sociedade Global - www.ufsm.br/redesg v. 3, n. 1, jan-jun/2014 
A ESPIONAGEM DOS ESTADOS UNIDOS DA AMÉRICA E A VIOLAÇÃO DA PRIVACIDADE DE DADOS PESSOAIS DOS BRASILEIROS NA INTERNET

MÁRCIO DE SOUZA BERNARDES E RODRIGO AGUIAR DA SILVA

Assembleia Geral da Organização das Nações Unidas, dentre as quais o discurso considerado mais resistente aos meios de vigilância adotados pelo governo norte-americano foi o da Presidente brasileira Dilma Rousseff, como já mencionado anteriormente.

A espionagem norte-americana introduziu um marco histórico no uso da Internet, na medida em que a anterior desterritorialização desta, com a inexistência de fronteiras por parte dos usuários, deixou de ser predominante em razão da proteção da soberania de cada Estado e da privacidade de seus habitantes. Diante disso, certos países como “o Brasil e a Alemanha começaram a trabalhar em uma resolução na Assembleia Geral da ONU para estabelecer limites à espionagem da NSA. A nova palavra de ordem era 'cibersoberania'”. ${ }^{56}$

Além de atuar no cenário internacional, o governo brasileiro também agilizou a tramitação do Marco Civil da Internet em seu âmbito interno, dando tramitação preferencial ao projeto de lei que estava paralisado há dois anos no Congresso Nacional, em razão das graves denúncias de espionagem ${ }^{57}$. Sancionado pela Presidente da República recentemente, no dia 23 de abril de 2014, o Marco Civil da Internet $^{58}$ recebeu elogios internacionalmente, sendo apontados três tópicos fundamentais e exemplares em seu conteúdo: a liberdade de expressão, a privacidade e a neutralidade da rede ${ }^{59}$.

Com isso, percebe-se que a espionagem digital estadunidense, apesar de todos os reflexos negativos, também rendeu uma consequência positiva, qual seja a atenção de vários Estados para a questão da segurança em Rede. Sendo inegável a presença e necessidade da Internet em vários aspectos do nosso cotidiano, é surpreendente que muitos países não tenham regulamentação jurídica específica no que tange à proteção das relações virtuais, tal como era a situação do Brasil antes da aprovação do Marco Civil da Internet. Tal legislação sem dúvidas é um avanço em relação à proteção da privacidade no âmbito virtual e, juntamente com outras represálias à ardilosa vigilância dos Estados Unidos da América, busca uma segurança internacional tanto política como jurídica.

\footnotetext{
${ }^{56}$ HARDING, Luke. Os arquivos Snowden: a história secreta do homem mais procurado do mundo. Rio de Janeiro: LeYa, 2014, p. 227.

57 ESTADÃO. Após denúncia de espionagem, Dilma pede urgência para Marco Civil da Internet. Disponível em < http://www.estadao.com.br/noticias/nacional,apos-denuncia-de-espionagem-dilmapede-urgencia-para-marco-civil-na-internet,1073638,0.htm>. Acesso em 21 maio de 2014.

${ }_{58}^{58}$ PORTAL PLANALTO. Lei 12.965/2014. Disponível em <http://www.planalto.gov.br/ccivil_03/_ato2011 2014/2014/lei//12965.htm>. Acesso em 04 dez. 2014.

59 OLHAR DIGITAL. Marco Civil da Internet é elogiado fora do Brasil. Disponível em < http://olhardigital.uol.com.br/noticia/41751/41751 >. Acesso em 23 maio de 2014.

REDESG / Revista Direitos Emergentes na Sociedade Global - www.ufsm.br/redesg v. 3, n. 1, jan-jun/2014
} 


\section{CONCLUSÃO}

Diante da análise exposta no presente trabalho, foi possível chegar a uma solução para o problema proposto, qual seja, o contraponto entre a relevância da proteção à segurança pública norte-americana e a magnitude do direito à privacidade dos dados pessoais dos brasileiros na Internet, em razão da espionagem revelada por Edward Snowden em junho de 2013.

Para tanto, foi preciso explorar todo um contexto histórico em relação aos motivos fundadores da atitude arbitrária dos Estados Unidos da América, além de averiguar o cenário internacional atual decorrente da globalização, a sociedade da informação e o tratamento da privacidade no âmbito das novas tecnologias. Perante esta conjuntura de elementos necessários ao entendimento do tema apresentado, chegou-se à conclusão que os direitos fundamentais, dentre eles a privacidade de dados pessoais, mesmo confrontados com um motivo aparentemente justo como o combate ao terrorismo, deve prevalecer em razão de sua inerente essencialidade. No estudo realizado, verifica-se todo um processo histórico de criação e adequação de normas protetoras dos direitos humanos fundamentais, não só no ordenamento jurídico pátrio, como também internacionalmente mediante tratados e convenções, motivo pelo qual não devem ser ignorados com o advento de um novo cenário político-social, seja fundamentado na defesa nacional ou mesmo por desejo de domínio tecnológico sobre o mercado econômico e a liberdade individual de todas as pessoas em sua esfera privada, indiscriminadamente.

Desse modo, verifica-se que a espionagem estadunidense violou gravemente um conjunto de normas imprescindíveis à segurança jurídica de diversas nações, dentre elas a Constituição dos Estados Unidos da América, a Constituição Federal Brasileira de 1988 e tratados internacionais de direitos humanos, inclusive um de suma importância histórica: a Declaração Universal dos Direitos do Homem de 1948. Outrossim, foram apontados grandes indícios de que a justificativa de prevenção ao terrorismo nada mais é do que um mero pretexto para o domínio norte-americano no âmbito internacional, visto que a captação de dados pessoais na sociedade da informação permite um poder incalculável a quem os detenha.

Assim, o desvio da missão originária dos órgãos de inteligência dos Estados Unidos da América, antes focados na proteção da segurança nos conflitos internacionais e agora vistos 
A ESPIONAGEM DOS ESTADOS UNIDOS DA AMÉRICA E A VIOLAÇÃO DA PRIVACIDADE DE DADOS PESSOAIS DOS BRASILEIROS NA INTERNET

MÁRCIO DE SOUZA BERNARDES E RODRIGO AGUIAR DA SILVA

como agentes sorrateiros na obtenção de informações privilegiadas de civis, permite a sobreposição do governo norte-americano sobre os demais. Caso não fossem reveladas, tais práticas poderiam levar até mesmo a um totalitarismo dos Estados Unidos da América com uma amplitude global, nação que seria detentora de um poder político extremamente opressor, violando os direitos mais fundamentais do indivíduo, especialmente no espaço digital.

Salienta-se, ainda, que o atual temor de vigilância dos usuários da Internet poderia levar a um desuso desta ferramenta tão importante para a comunicação humana, inevitavelmente necessária hodiernamente. Não se pode permitir que a espionagem e a interferência estatal causem um retrocesso no campo das novas tecnologias, que tanto contribuíram para a evolução do mundo moderno e nos levaram a uma sociedade sem fronteiras que prioriza a cooperação internacional das nações, colocando em risco a existência de uma solidariedade mundial entre os países.

Conclui-se, portanto, que a defesa de um único Estado não o autoriza a prejudicar todos os demais com uma espionagem virtual, diante da essencialidade da privacidade de cada indivíduo como direito humano fundamental, além de atentar contra a soberania e provocar diversos riscos à existência da democracia em âmbito internacional. Diante disso, a solução que se propõe é a cooperação internacional entre os países para o fortalecimento das normas jurídicas no que concerne à proteção da privacidade como direito fundamental, mediante a criação de normas mais específicas tanto na seara internacional, por meio de tratados internacionais, quanto no ordenamento jurídico de cada nação.

\section{REFERÊNCIAS}

ALVES, José Augusto Lindgren. Cidadania, direitos humanos e globalização. In: PIOVESAN, Flávia (coord.). Direitos humanos, globalização econômica e integração regional: desafios do direito constitucional internacional. São Paulo: Max Limonad, 2002.

BBC BRASIL. Dilma diz em Assembleia da ONU que espionagem é grave violação dos direitos humanos. Disponível em:

<http://www.bbc.co.uk/portuguese/noticias/2013/09/130924_dilma_assembleia_onu_lgb.sht'm l>. Acesso em: 24 out. 2013.

BOFF, Salete Oro; DIAS, Felipe de Veiga Dias. Direito à privacidade online: um sonho virtual ou uma realidade constitucionalmente possível?. In: ADOLFO, Luiz Gonzaga Silva (coord.). Direitos Fundamentais na Sociedade da Informação. Florianópolis: UFSC/GEDAl, 2012. 
CACHAPUZ, Maria Cláudia. Intimidade e vida privada no novo Código Civil Brasileiro: uma leitura orientada no discurso jurídico. Porto Alegre: Sergio Antonio Fabris Ed., 2006.

CASTRO, Catarina Sarmento e. Direito da informática, privacidade e dados pessoais. Coimbra: Ed. Almedina, 2005.

COMISSÃO NACIONAL DE PROTECÇÃO DE DADOS. Lei da protecção de dados pessoais. Disponível em: <http://www.cnpd.pt/bin/legis/nacional/lei_6798.htm>. Acesso em: 04 dez. 2014.

DIAS, Felipe da Veiga; REIS, Jorge Renato dos. A Constituição como suporte ético às relações humano-virtuais: contributos da hermenêutica jurídica para o estabelecimento de fundamentos axiológicos no contexto da sociedade da informação. In: BOFF, Salete Oro; BORTOLANZA, Guilherme. Direitos Fundamentais e Novas Tecnologias. Florianópolis: Conceito Editorial, 2012.

DONEDA, Danilo. Da privacidade à proteção de dados pessoais. Rio de Janeiro: Renovar, 2006.

ESTADÃO. Após denúncia de espionagem, Dilma pede urgência para Marco Civil da Internet. Disponível em: <http://www.estadao.com.br/noticias/nacional,apos-denuncia-de-espionagemdilma-pede-urgencia-para-marco-civil-na internet,1073638,0.htm>. Acesso em: 21 mai. de 2014.

FERRAZ JR., Tércio Sampaio. Sigilo de dados: o Direito à privacidade e os limites à função fiscalizadora do Estado. Disponível em:

<http://www.terciosampaioferrazjr.com.br/?q=/publicacoes-cientificas/28>. Acesso em: 03 set. 2013.

G1. Dilma diz na ONU que espionagem fere soberania e direito internacional. Disponível em: <http://g1.globo.com/mundo/noticia/2013/09/dilma-diz-na-onu-que-espionagem-feresoberania-e-direito-internacional.html>. Acesso em: 25 set. 2013.

G1. Entenda o caso de Edward Snowden que revelou espionagem dos EUA. Disponível em: <http://g1.globo.com/mundo/noticia/2013/07/entenda-o-caso-de-edward-snowden-querevelou-espionagem-dos-eua.html>. Acesso em: 10 set. 2013.

G1. Ministério das Minas e Energia está na mira dos espiões americanos e canadenses. Disponível em <http://g1.globo.com/fantastico/noticia/2013/10/ministerio-das-minas-eenergia-esta-na-mira-de-espioes-americanos-e-canadenses.html>. Acesso em 07 out. 2013.

G1. Petrobras foi alvo de espionagem de agência dos EUA, aponta documento. Disponível em <http://g1.globo.com/politica/noticia/2013/09/petrobras-foi-alvo-de-espionagem-de-agenciados-eua-aponta-documento.html>. Acesso em 09 set. 2013.

G1. Veja os documentos ultrassecretos que comprovam espionagem a Dilma. Disponível em: <http://g1.globo.com/fantastico/noticia/2013/09/veja-os-documentos-ultrassecretos-quecomprovam-espionagem-dilma.html>. Acesso em: 03 set. 2013.

GEDIEL, J. A. P.; CORRÊA, A. E. Proteção jurídica de dados pessoais: a intimidade sitiada entre o Estado e o mercado. Revista da Faculdade de Direito - UFPR, Curitiba, n. 47, 2008.

REDESG / Revista Direitos Emergentes na Sociedade Global - www.ufsm.br/redesg v. 3, n. 1, jan-jun/2014 
HARDING, Luke. Os arquivos Snowden: a história secreta do homem mais procurado do mundo. Rio de Janeiro: LeYa, 2014.

LASMAR, Jorge Mascarenhas. Terrorismo Internacional e Globalização: A reestruturação do sistema internacional. In: BRANT, Leonardo Nemer Caldeira. Terrorismo e Direito: os impactos do terrorismo na comunidade internacional e no Brasil. Rio de Janeiro: Forense, 2003.

LEMOS, André; LÉVY, Pierre. O futuro da internet: em direção a uma ciberdemocracia planetária. São Paulo: Paulus, 2010.

LIMBERGER, Têmis. Direito e informática: o desafio de proteger os direitos do cidadão. In: SARLET, Ingo Wolfgang (coord.). Direitos fundamentais, informática e comunicação: algumas aproximações. Porto Alegre: Livraria do Advogado, 2007.

MARCACINI, Augusto Tavares Rosa. Direito e informática: uma abordagem jurídica sobre a criptografia. Rio de Janeiro: Forense, 2002.

MATIAS, Eduardo Felipe Pérez. A humanidade e suas fronteiras: do Estado soberano à sociedade global. São Paulo: Paz e Terra, 2005.

MEIRA, Laís Moreschi de; PIRES, Panmella Rodrigues; SOARES, Matheus Fernandes de Souza. Direito à privacidade e as relações na Internet. Disponível em:

<http://www.jurisway.org.br/v2/dhall.asp?id_dh=7319>. Acesso em: 10 nov. 2013.

MIRANDA, Jorge. Os direitos fundamentais perante o Terrorismo. In: BRANT, Leonardo Nemer Caldeira. Terrorismo e Direito: os impactos do terrorismo na comunidade internacional e no Brasil. Rio de Janeiro: Forense, 2003.

OLHAR DIGITAL. Marco Civil da Internet é elogiado fora do Brasil. Disponível em: <http://olhardigital.uol.com.br/noticia/41751/41751>. Acesso em: 23 maio de 2014.

O GLOBO. EUA justificam espionagem por ameaças terroristas. Disponível em: <http: / /oglobo.globo.com/mundo/eua-justificam-espionagem-por-ameacas-terroristas8869281>. Acesso em: 14 jul. 2013.

O PAÍS ONLINE. Dilma diz que espionagem dos EUA é grave violação dos direitos humanos. Disponível em: <http://www.opais.co.mz/index.php/internacional/56-internacional/27246dilma-diz-que-espionagem-dos-eua-e-grave-violacao-dos-direitos-humanos-macia.html>. Acesso em: 21 out. 2013.

ORWELL, George. 1984. São Paulo: Companhia das Letras, 2009.

PAESANI, Liliana Minardi. Direito e Internet: liberdade de informação, privacidade e responsabilidade civil. 3. ed. São Paulo: Atlas, 2006.

PEREIRA, Marcelo Cardoso. Direito à intimidade na internet. 1. ed., 3. tir. Curitiba: Juruá, 2005. 
PORTAL PLANALTO. Constituição da República Federativa do Brasil de 1988. Disponível em: <http://www.planalto.gov.br/ccivil_03/constituicao/constituicao.htm>. Acesso em: 04 nov. 2013.

RUARO, Regina Linden; RODRIGUEZ, Daniel Piñeiro. Nada a esconder? 0 direito à proteção de dados frente a medidas de segurança pública e intervenção estatal. Disponível em <http://www.ambitojuridico.com.br/site/index.php?n_link=revista_artigos_leitura\&artigo_id=95 42\&revista_caderno=4>. Acesso em: 09 set. 2013.

SAMPAIO, José Adércio Leite. Constituição e Terror - uma visão parcial do fenômeno terrorista. In: BRANT, Leonardo Nemer Caldeira. Terrorismo e Direito: os impactos do terrorismo na comunidade internacional e no Brasil. Rio de Janeiro: Forense, 2003.

SPALDING, Alessandra Mendes. As leis terroristas norte-americanas e os direitos humanos. In: RIBEIRO, Maria de Fátima (coord.). Direito internacional dos direitos humanos: estudos em homenagem à Prof ${ }^{a}$. Flávia Piovesan. 3. tir. Curitiba: Juruá, 2006.

WACHOWICZ, Marcos. A sociedade da informação e direitos humanos. In: RIBEIRO, Maria de Fátima (coord.). Direito internacional dos direitos humanos: estudos em homenagem à Profa . Flávia Piovesan. 3. tir. Curitiba: Juruá, 2006. 